\title{
Physicochemical characteristics and storage stabilities of soy sauce and soybean paste sauce added with extracts of pear and sugar
}

\author{
Yeon-Ok Park* \\ Department. of Food and Nutrition, Songwon University, Gwangju 61756, Korea
}

\section{배당침액을 첨가한 간장소스와 된장소스의 이화학적 특성 및 저장성}

\author{
박연옥* \\ 송원대학교 식품영양학과
}

\begin{abstract}
This study was conducted to investigate the physicochemical characteristics and storage stabilities of soy sauce and soybean paste sauce added with extracts of pear and sugar. The commercial possibility of these sauces was investigated by sensory and preference evaluations. First, the sensory evaluation of two different particle sizes of soybean paste sauce (Type I , chopped; Type II, ground) was performed. The result of sensory and preference evaluations of soybean paste sauce Type I was higher than those of soybean paste sauce Type II, which the former was used for further analysis. The total polyphenol contents and the 2,2'-azino-bis (3-ethylb enzothiazoline-6-sulfonic acid) (ABTS - +) radical scavenging activities of two sauces were not significantly different $(\mathbf{p}<0.05)$. The 2,2-Diphenyl-1-picrylhydrazyl (DPPH) radical scavenging activity of soy sauce was higher than that of soybean paste sauce I $(\mathbf{p}<0.05)$. The $\mathbf{p H}$, total bacterial count, saltiness, and hunter's color values of both sauces were not changed during the whole storage period $(60$ days). Viscosity of the soybean paste sauce I was increased while the viscosity of soy sauce was significantly decreased during the storage periods $(p<0.05)$. From these results, it was suggested that the soy sauce and soybean paste sauce I added with pear extract of pear and sugar would be a suitable sauce for smoked duck and meat foods.
\end{abstract}

Key words : pear, soy sauce, soybean paste sauce, physicochemical, storage stability

\section{서 론}

현대사회는 경제성장과 더불어 소비자들의 건강에 대한 관심이 높아져 천연물을 이용한 식품에 대한 선호도가 높아 지고 이와 관련된 제품 개발이나 연구가 활발히 진행되고 있는 추세이다. 생리활성을 갖는 다양한 천연물의 활용은 주로 유기용매로 특정성분을 추출하여 여러 가지 생리활성 을 가지는 물질탐색에 대한 연구와 그 활용에 관한 연구가 주를 이루고 있고, 이를 활용하여 기능성 식재료뿐만 아니

*Corresponding author. E-mail : smilegem0512@songwon.ac.kr Phone : 82-62-360-5868, Fax : 82-62-360-3972

Received 10 June 2015; Revised 27 July 2015; Accepted 11 August 2015.

Copyright (c) The Korean Society of Food Preservation. All rights reserved.
라 천연 의약품 개발에 집중되고 있다. 최근에 산야초의 잎이나 열매 등을 설탕과 동량으로 혼합하여 일정기간 발효 시킨 것을 산야초 효소라는 명칭으로 시중에 통용되고 있는 데 실제 실험 결과 효소활성이 낮아 효소액이라는 명칭보다 는 당침액이나 청 등의 용어의 사용이 바람직하다고 하였 다. 그리고 이런 당침액은 제조 중 항산화능이 증가하므로 기능성이나 당의 보충을 요하는 음료의 원료 또는 식재료로 서는 충분히 가치가 있는 것으로 알려졌다(1).

배는 우리 몸에 유익한 대표적인 알칼리성 식품으로서, 먹을 수 있는 가식율이 80 82\%, 수분함량이 85 88\%이며 열량은 $39 \mathrm{kcal} / 100 \mathrm{~g}$ 정도이다. 열량의 주성분은 탄수화물 이며, 이중 단맛을 내는 당분은 10 13\%로 품종에 따라 차이 가 많다. 단백질 함량은 $0.3 \%$ 내외로서 다른 과실과 큰 차이가 없으나, 식이섬유 함량이 높아 변비 및 정장작용이 탁월하다(2). 배를 연구한 많은 보고서에 의하면 배에는 
chlorogenic acid, rutin, procyanidins, catechin, epicatechin, arbutin(4-hydroxyphenyl- $\beta$-D-glucopyranoside)등 폴리페놀 (polyphenol), 플라보노이드(flavonoids)등의 성분이 많이 함유되어 있어 항암, 항염증, 및 항산화 효과가 뛰어난 것으 로 밝혀져 많은 관심을 끌고 있다(3). 배를 이용한 가공품 연구는 Rosa 등의 배즙 malic acid의 항균효과(4)와 김치로 부터 분리한 Leuconostoc mesenteroides 51-3을 배양하여 발효된 배퓨레의 발효 특징(5), 배 첨가가 막걸리의 품질과 생리 기능성에 미치는 영향(6), 고품질 배 와인 제조를 위한 최적 발효 조건과 품질 특성(7), 배와 과채류를 이용한 유산 균 발효음료(8), 공기와 화학첨가제 조절에 의한 신선편이 배의 품질변화(9), 배즙과 배건조 분말을 첨가한 배양갱(10) 등의 연구가 진행되었으며 주로 음료나 술, 생과에 치중되 어 있다. 소스류에서는 배에 함유되어 있는 소화효소인 인 베르타아제와 옥시다제에 의해 육회·불고기·갈비 등의 육 질을 부드럽게 하기 위해 연육제로서 기본 소스에 부가적으 로 첨가되는 재료로만 사용되고 있어(2) 배의 기능성 성분 을 활용한 제품 및 소스 등 다양한 방면으로 연구가 필요한 실정이다.

소스는 고대 로마시대부터 요리의 맛과 색상을 내기 위 하여 사용되어온 액체 또는 반 유동상의 조미료로서 '소금 을 기본으로 한 조미액'을 의미하는 라틴어의 'Salsa'에서 유래되었다. 이러한 소스는 음식의 맛과 냄새 및 색상을 좋게 하여 식욕을 증진시키고 영양가를 높이면서 수분을 유지시켜 주며, 조리과정 중 재료들을 서로 결합시켜 음식 이 조화를 이루게 한다(11). 최근에 식생활의 서구화와 동서 양 음식의 퓨전화로 인해 많은 음식에 소스를 곁들여 먹게 되었고 이에 따라 다양한 음식에 맞는 여러 가지 소스의 개발이 요구되고 있으며, 특히 천연 재료가 다양한 생리활 성 기능을 가진 것으로 밝혀짐에 따라 이들 자원으로부터 생리활성을 탐색하고, 기능성식품으로 개발하고자 하는 연 구가 집중되고 있다.

한식에서 간장을 이용한 소스는 짠맛, 단맛, 감칠맛 등이 조화되어 불고기, 갈비, 닭찜 등에 두루 사용되고 있는데, 간장 소스 개발과 관련된 연구를 보면 사과농축액을 이용한 간장조림소스(12), 오미자즙을 첨가한 불고기 소스(13), 산 수유 열추출물을 첨가한 간장소스(14), 국산 간장을 이용한 데리야끼 소스의 제조(15), 헛개열매와 배 추출물을 첨가한 향신간장 소스의 관능평가(16) 등 다양한 식재료를 활용한 다용도 간장 소스에 관한 연구가 활발히 진행되고 있다. 된장은 전통적인 맛과 향을 지닌 대두 발효식품으로서 탄수 화물 원료에 Aspergillus sp.의 균을 이용하여 대두와 함께 제조한 것으로 우리나라의 대표적인 조미식품이다(17). 된 장의 원료인 콩은 isoflavone, chlorogenic acid isomers, caffeic acid, ferulic acid 등이 함유되어 항산화성이 우수한 것으로 알려져 있으며(18), 대두 발효식품에는 항산화효과 를 나타내는 물질이 확인되었고(19), 혈압강하능력(20)과
혈전용해능(21)등의 기능성이 있는 것으로 알려져 있다. 된장 소스와 관련된 연구는 단호박 된장소스(22), 호두와 참개를 첨가한 된장소스(23) 등이 있지만 아직 연구가 미흡 한 실정이다.

따라서 본 연구에서는 다양한 약리작용과 뛰어난 기능성 물질을 갖고 있는 배를 활용하는 일환으로서 배를 가공하여 소스 개발에 이용하고자 하였다. 배를 소스 만드는 주재료 로 사용하기 위해 배당침액을 만들었으며 이를 이용하여 간장 소스와 된장 소스를 제조하였다. 또한 개발한 두 소스 의 기능성 및 관능검사를 실시하였고 60 일 저장기간 동안 의 이화학적 변화를 분석하여 각각 소스의 결과 자료를 기본 자료로 하여 육류요리에 잘 어울리는 소스로 제안하고 자 한다.

\section{재료 및 방법}

\section{실험 재료}

배당침액과 2종 소스 제조에 사용된 배, 마늘, 양파, 간장 (Chungjungone, Seoul, Korea), 된장(Chungjungone, Seoul, Korea), 사과식초(Ottogi, Anyang, Korea) 발사믹식초 (Chungjungone, Seoul, Korea), 구아검(Somang, Daejeon, Korea) 등은 농협 대형마트에서 구매한 것을 사용하였다. 배는 우리나라에서 재배되는 주품종인 신고를 이용하여 배당침액을 제조하였다(Fig. 1). 배는 잘 씻은 후 물기를 제거하고 과심만 도려내어 껍질째 이용해 황설탕과 설탕을 $1: 1$ 의 비율로 섞어 당침, 밀봉 하여 $25^{\circ} \mathrm{C}$ 실온에 3 개월 저장 후 배는 건져내고 배당침액만 밀봉하여 냉장실에 보관하며 시료로 사용하였다. 초기 1 개월간은 1 주마다 당침액이 균 질해지도록 섞어 주었다.

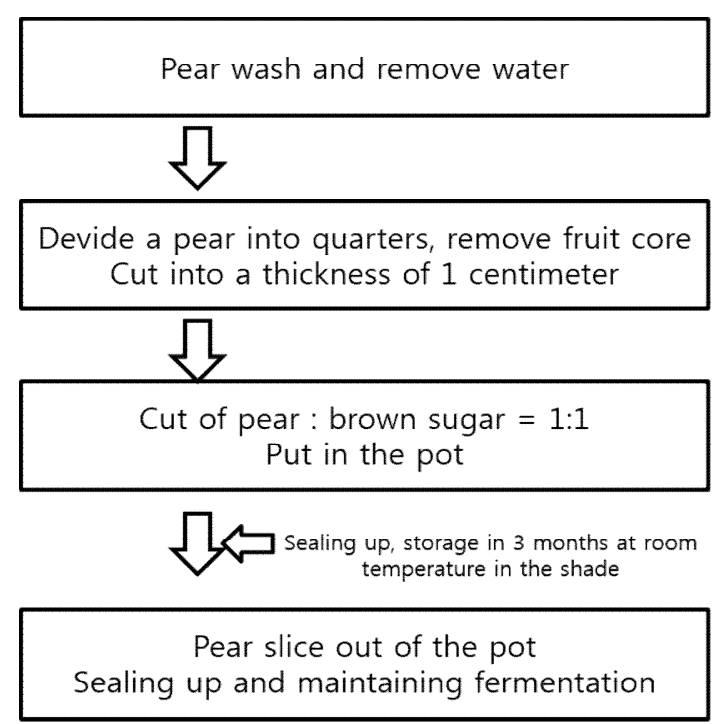

Fig. 1. Experimental procedure for extracts of pear by sugar. 


\section{소스 제조}

본 연구에 제시한 배당침액을 첨가한 간장소스와 된장소 스를 개발하기 위하여 이론적 표준 레시피를 수집(24-26)하 고 실험 조리와 관능평가를 실시하여 재료와 분량, 만드는 방법 등 레시피를 결정하여 본 연구를 실시하였다. 간장소 스와 된장소스의 기본 재료는 Table 1 과 같은 조성으로 만들었다. 간장소스의 육수는 다시마와 오리빼, 무, 양파, 대파, 마늘 등으로 3시간 우려내어 이용하였고, 소스 재료 각 분량의 간장, 배당침액, 케첩, 미림을 넣어 $1 / 3$ 분량으로 조린 후 사과식초를 넣고 구아검과 물전분으로 농도 조절 후 소금을 넣어 간을 맞추고 마지막으로 발사믹 식초를 넣어 끓으면 불을 끄는 과정으로 만들었다. 된장소스는 개 량된장, 배당침액, 배, 식초를 넣어 분쇄기에 곱게 갈아주고 마늘과 양파는 $0.2 \mathrm{~cm}$ 크기로 잘 다진 후 재료를 섞어 소금 으로 간을 맞췄다. 된장소스는 관능평가에서만 재료의 입 자 크기가 미치는 영향을 보기 위해 마늘과 양파를 다져서 만든 소스(된장소스 I)와 분쇄기에 갈아서 만든 소스(된장 소스 I) 두 가지 형태로 만들었다.

\section{관능평가}

배당침액을 첨가한 2종 소스의 관능검사는 강도 특성 검사와 기호도 검사로 나누어 정량적 묘사 분석(quantitative descriptive analysis, QDA)으로 진행하였다. 배당침액을 첨 가한 2종 소스를 개발하기 위하여 먼저 된장소스는 마늘, 양파입자의 크기가 소스의 관능평가와 기호도 평가에 미치 는 영향을 알아보고 추 후 한 가지 소스만 선택해 이화학적 분석을 실시하고자 두 가지 형태로 제조하였다. 된장소스 $\mathrm{I}$ 은 마늘과 양파를 $0.2 \mathrm{~cm}$ 크기로 다져 소스를 만들었고 된장소스 프는 마늘과 양파를 분쇄기에 갈아서 소스를 만들 었다.

강도 특성 검사는 훈련된 식품영양학과 학부학생 20명을 패널로 선정하여 검사방법과 평가특성을 사전 교육시킨
후 9점 척도법(9-point hedonic scale)을 사용하여 최고 9점에 서 최저 1점까지 특성이 강할수록 높은 점수를 주도록 하였 다. 외관의 강도는 소스의 특성을 부여하는 걸쭉함이나 윤 기, 색 등이 얼마나 잘 조화가 되었느냐에 따라 외적으로 보이는 정도를 범위 내에서 체크하였다. 색의 강도는 간장 과 된장소스가 각각 재료와 어우러져서 내는 종합적인 색 정도에 따라 구분하였다. 또한 맛의 강도는 각 소스 재료가 어우러져서 내는 간장 및 된장 소스가 표출하는 맛에 따라 그 적절성 정도를 강도로 표시하도록 하였다. 향미의 강도 는 각 소스의 재료가 어우러져 내는 소스 특유의 향 및 좋은 이미지의 향의 정도를 표시하게 하였고 이취는 소스를 맛 보았을 때 느껴지는 불쾌한 향 혹은 부정적인 이미지의 향의 정도를 표시하게 하였으며 후미는 맛을 본 후 입안에 남는 정도를 표시하였다. 점도는 소스로서 알맞은 걸쭉한 정도를 제시한 후 비교하여 그 강도를 표시하게 하였다. 전체적인 품질은 외관, 맛, 냄새, 향 등 각 소스의 전체적인 특성을 통합하여 느껴지는 정도를 강도로 더 좋은 쪽을 9점으로 하여 표시하게 하였다.

소스는 일정한 양을 $(20 \mathrm{~mL})$ 일회용 접시에 담아 제공하 였으며 한 개의 시료를 평가 후 반드시 생수로 입안을 헹구 고 다른 시료를 평가하도록 하였다. 관능검사 평가 항목으 로는 외관, 향미, 색깔, 이취, 맛, 후미, 점도, 전체적인 품질 을 평가하였다.

배당침액을 첨가한 3 종 소스의 기호도 검사는 훈제오리 와의 조화도를 보기 위해 훈제오리를 구워 2 종 소스와 함께 제공하여 실시하였다. 관능요원은 성인 100 명을 대상으로 하여 외관, 향미, 색깔, 산미, 걸죽함, 오리훈제와의 어울림, 전체적인 기호도 등의 조화도를 평가하였으며 배당침액 첨가한 2종 소스에 대한 강도 특성 검사와 같은 방법으로 실시하였다. 관능검사 척도는 9점 척도법으로 3회 반복하 여 실시하였다.

Table 1. Formular of (a) soy sauce, (b) soybean paste sauce I added with extracts of pear by sugar

(a)

\begin{tabular}{lc}
\hline \multicolumn{1}{c}{ Ingredient } & Quantity $(\mathrm{g})$ \\
\hline Soy sauce & 25 \\
Extracts of pear by & 65 \\
sugar & 50 \\
Refined rice wine & 20 \\
Catsup & 250 \\
Meat stock & 10 \\
Apple vinega & 20 \\
Balsamic vinegar & 1 \\
Guagum & 5 \\
Starch & 2.5 \\
Salt & \\
\hline
\end{tabular}

(b)

\begin{tabular}{lc}
\hline \multicolumn{1}{c}{ Ingredient } & Quantity (g) \\
\hline soybean paste sauce & 30 \\
Extracts of pear by & 70 \\
sugar & 150 \\
Pear & 40 \\
Union & 7 \\
Smash garlic & 30 \\
Apple vinegar & 3 \\
Salt & \\
\hline
\end{tabular}




\section{일반성분 분석}

배당침액과 2 종 소스의 일반성분 분석은 식품공전 일반 성분시험법(27)에 따라 다음과 같이 분석하였다. 조단백질 함량은 Kjeltec analyzer(Auto 1030, Tecator Co., Sweden)를 이용하여 micro-Kjeldahl법, 조지방 함량은 Soxhelt법으로, 수분함량은 상압가열건조법으로 측정하였다. 열량은 탄수 화물과 단백질은 $4 \mathrm{kcal} / \mathrm{g}$, 지방은 $9 \mathrm{kcal} / \mathrm{g}$ 를 곱하여 나온 값으로 계산하였다. 조회분은 회분측정법을 이용하였으며 탄수화물의 함량은 $100 \%$ 에서 단백질, 지질, 회분, 수분을 제한 값으로 계산하였다. 유리당 함량은 시료를 $0.45 \mu \mathrm{m}$ syringe filter로 여과하여 분석시료로 이용하였고, 분석기는 HPLC(WATERS, US/717)를 이용하였다. 칼럼은 Sugar-pak $(6.5 \times 300 \mathrm{~mm}$, Agilent Technologies, USA), 이동상은 Methanol-water(25:75 V/V), 검출기는 Watertm 600S detector, 유속 $0.5 \mathrm{~mL} / \mathrm{min}$, 주입량 $20 \mu \mathrm{L}$ 로 하였다. 표준물 질은 sucrose, fructose, glucose, galactose, manitol, sorbitol를 사용하였다.

\section{총 폴리페놀 함량}

배당침액과 2 종 소스는 각각 원액과 증류수 10 배 희석액 을 시료로 사용하였다. 각 시료의 총 폴리페놀 함량은 AOAC의 Folin-Denis법을 일부 수정하여 Folin-reagent가 추출물의 페놀성 화합물에 의해 환원되어 몰리브덴청색으 로 발색되는 원리를 이용하여 정량하였다(28). 즉 각 시료 $100 \mu \mathrm{L}$ 에 $2 \% \mathrm{Na}_{2} \mathrm{CO}_{3} 2 \mathrm{~mL}$ 를 넣어 30 분간 방치한 후 $50 \%$ Folin-Ciocalteu 시약 $100 \mu \mathrm{L}$ 넣은 후 혼합하여 30분간 방치 하고 spectrometer(Gene Spec III, JP/U-3010, Hitachi, Ibaraki, Japan)를 이용하여 $750 \mathrm{~nm}$ 에서 흡광도를 측정하였 다. 표준물질로는 gallic acid를 사용하였으며, gallic acid 검량선과 비교하여 총 폴리페놀 함량 $(\mathrm{mg} / 100 \mathrm{~g})$ 을 구했다. 실험은 반복 수행하여 평균값을 사용하였다.

\section{$\mathrm{DPPH}$ radical 소거능}

배당침액과 2 종 소스류는 각각 원액과 증류수 10 배 희석 액의 항산화 활성 중 전자공여능은 안전한 라디칼인 DPPH(2,2-diphenyl-1-picrylhydrazyl)에 대한 환원력을 측정 한 것으로 Blios법을 변형하여 측정하였다(29). 즉, $99.9 \%$ 에탄올에 녹인 $0.2 \mathrm{mM} \mathrm{DPPH}$ 용액 $0.8 \mathrm{~mL}$ 과 각 시료 0.2 $\mathrm{mL}$ 를 가하여 잘 혼합하고 30 분간 실온에 방치하였다. 이후 $\mathrm{DPPH}$ 용액의 흡광도를 spectrometer(Gene Spec III, JP/U3010 , Hitachi, Ibaraki, Japan)를 이용하여 $520 \mathrm{~nm}$ 에서 측정 하였다. DPPH radical 소거능(\%)은 시료첨가구와 비첨가구 의 흡광도 차이를 백분율로 표시하였다.

DPPH radical 소거능 $(\%)=[1-($ 실험구의 흡광도 1 대조구의 흡광도) $] \times 100$

\section{$A B T S$ radical 소거능}

$\operatorname{ABTS}(2,2$ '-azino-bis(3-ethylbenzothiazoline-6-sulfonic acid) radical 소거능 측정은 Shiddhuraju 등(30)의 방법을 변형하여 측정하였다. ABTS $7.0 \mathrm{mM}$ 에 증류수에 용해한 potassium persulfate $140 \mathrm{mM}$ 을 넣고 16시간 동안 암소에 방치하여 $\mathrm{ABTS}^{+}$radical을 생성시켰다. 라디칼이 생성된 용액을 $734 \mathrm{~nm}$ 에서 $0.700( \pm 0.05)$ 의 흡광도를 갖도록 조정 하였다. 소거활성은 $\mathrm{ABTS}^{++}$radical solution $950 \mu \mathrm{L}$ 와 시료 액 $50 \mu \mathrm{L}$ 를 혼합하여 $734 \mathrm{~nm}$ 에서 6분 후 흡광도를 측정하였 다. $\mathrm{ABTS}^{++}$radical 소거능은 시료 첨가구와 무 첨가구의 흡광도를 이용하여 백분율로 나타내었다.

$$
\begin{gathered}
\mathrm{ABTS}++ \text { radical 소거능 }(\%)=[1-(\text { 실험구의 흡광도 } \\
\text { 대조구의 흡광도) }] \times 100
\end{gathered}
$$

\section{$\mathrm{pH}$, 당도, 염도}

배당침 액을 첨가한 2 종 소스는 $50 \mathrm{~mL}$ 튜브에 담아 냉장 고에서 저장하며 60 일 저장기간 동안의 $\mathrm{pH}$ 변화는 각 시료 $10 \mathrm{~g}$ 에 증류수 $90 \mathrm{~mL}$ 에 희석시키고 $\mathrm{pH}$ meter $(\mathrm{pH}-200 \mathrm{~L}$, Schawarzenbach, Switzlerland)로 5회 반복 측정하여 평균값 을 구하였다. 당도는 상온에서 digital refractometer(PDX-1, Vee Gee, USA)를 이용하여 3회 이상 평균값으로 나타내었 고, ${ }^{\circ} \mathrm{Brix}$ 로 표시하였다. 염도는 소스에 염도계(SS-31A, Sekisui, Japan)를 넣어 실온에서 직접 측정하였다. 단위는 $\%$ 로 나타내었으며, 수치는 3회 이상 반복한 후 그 평균값으 로 나타내었다.

\section{미생물수}

일반 세균수와 대장균군 검사는 각 시료 $1 \mathrm{~mL}$ 를 $3 \mathrm{M}$ petrifilm plate(일반 세균: aerobic count plates, 대장균군: E. coli/coliform count plate, 3M Korea, Seoul, Korea)에 분주 하여 배양기에서 $37^{\circ} \mathrm{C}, 48$ 시간 배양하여 colony 수를 측정 하였다.

\section{색도}

배당침액을 첨가한 2 종 소스 색은 색차계 spectrophotometer (CM-3500D, Minolta Co., LTD., Japan)를 이용하여 측정하 였다. 측정 전 표준백판 $(\mathrm{L}=96.90, \mathrm{a}=0.21$ 및 $\mathrm{b}=2.21)$ 으로 보정한 후 사용하였으며 $\mathrm{L}$ (명도, lightness), a(적색도, redness), b(황색도, yellowness)등을 각각 5 회 이상 측정하 여 평균값을 구하였다.

점도

배당침액을 첨가한 2 종 소스의 점도는 점도계 (BROOKFIELD DV-III ULTRA, Middleboro, USA)로 물성 분체 cell을 이용하여 점성을 측정하였다. 측정조건은 $25^{\circ} \mathrm{C}$ 로 온도를 유지한 소스를 $500 \mathrm{~mL}$ 용기에 $400 \mathrm{~mL}$ 씩 담은 
후 간장 소스는 $120 \mathrm{rpm}$, 된장 소스는 $180 \mathrm{rpm}$ 에서 spindle No. 2 을 사용하여 1 분간 측정한 후 그 수치를 기록하여 각 3회 이상 반복한 후 그 평균값으로 나타내었다.

\section{통계분석}

실험에서 얻어진 성적은 SPSS(18.0, SPSS Inc, Chicago, IL, USA)를 이용하여 분석하였으며, 시료 간 유의성 차이는 $\mathrm{t}$-검정, 분산분석을 이용하여 실시한 유의성이 있는 경우에 Duncan 다중범위검정(Duncan's multiple range test)으로 시 료간의 유의차를 검증하였다 $(\mathrm{p}<0.05)$.

\section{결과 및 고찰}

\section{관능평가}

배당침액을 첨가하고 마늘과 양파의 입자의 크기를 달리 하여 제조한 두 가지 형태의 된장소스 관능평가 결과는 Fig. 2에 나타내었다. 소스의 강도평가에서는 된장소스 I 이 향미와 맛, 전체적인 품질 등 $(\mathrm{p}<0.05)$ 에서 유의적으로 된장소스 ㅍㅂ보다 높게 나타났고 외관이나 이취, 색깔, 점도 등은 차이가 없었다. 기호도 평가에서는 마늘과 양파를 0.2 $\mathrm{cm}$ 크기로 다져서 만든 된장소스 I이 색깔, 맛, 산미, 훈제 오리와의 조화, 전체적인 기호도 등 $(\mathrm{p}<0.05)$ 에서 유의적으 로 된장소스 П보다 높게 나왔다. 이는 된장소스 П는 된장 소스 I에 비해 마늘과 양파를 분쇄기에 갈아 입자가 미세 해짐으로서 훈제오리 섭취 후 입안에 텁텁함이 남고 개운함 이 감소해서 나타난 결과라고 사료된다. 그러나 된장소스 I 은 마늘과 양파의 입자가 입안에서 씹히면서 훈제오리 섭취 후 입안에 남았던 기름진 후미를 개운하게 제거를 해주고 일반적으로 된장 숙성과정에서 생성된 담백한 맛과 신맛, 단맛 등이 어우러져 일상적으로 한국인의 입맛에 잘 맞기 때문에 훈제오리와도 잘 맞고 전체적인 선호도가 높게 나타났다고 사료된다(31). 따라서 이러한 관능평가 결과를 기본으로 하여 배당침액을 첨가한 된장소스는 마늘과 양파 를 다져서 만드는 된장소스 I 을 간장소스와 관능평가를

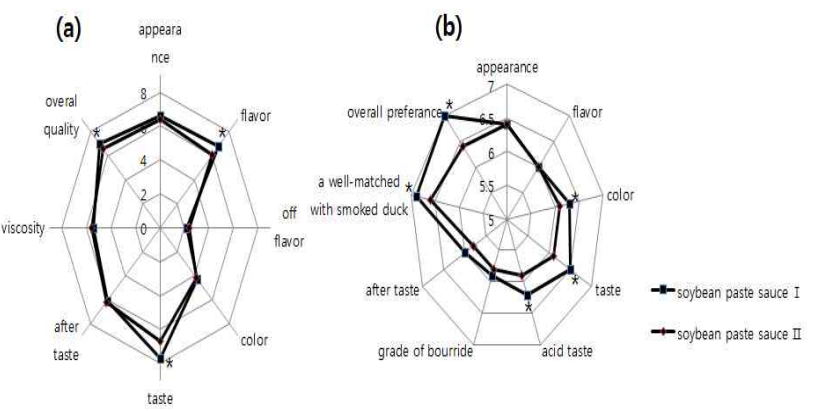

Fig. 2. Sensory evaluation of soybean paste sauce I and II added with extracts of pear by sugar.

(a), Sensory evaluation; (b), Preference. * Values with different superscripts are significantly different at the $p<0.05$ by $t$-test.
비교하고 이화학적 분석 시료로 사용하였다.

배당침액을 첨가한 간장소스와 된장소스 I 의 관능평가 결과는 Fig. 3 에 나타내었다. 간장소스는 이취, 색깔, 점도의 강도가 높았으며 된장소스 I 은 향미, 맛, 전체적인 품질 등 $(\mathrm{p}<0.05)$ 이 높았다. 소스 섭취 후 입안에 남는 정도를 나 타내는 후미의 강도는 된장소스 I이 간장소스 보다는 높았 다. 그러나 이취는 된장소스 I이 간장소스 보다 유의적으 로 낮아 소스로서의 긍정적인 결과를 보였다. 색깔은 간장 소스가 강도가 유의적으로 높았으며 $(\mathrm{p}<0.05)$ 반면 된장소 스 I은 그 정도가 낮았다. 이는 간장과 된장 특유의 색과 평상시 접했던 소스의 색 이미지에 대한 판단 정도가 영향 을 미쳤다고 사료된다. 각 소스의 외관에 대한 강도 평가는 유사하였다. 전체적인 품질에 대한 평가는 된장소스 I이 간장소스 보다는 유의적으로 높았다( $\mathrm{p}<0.05)$. 간장소스가 외관이나 색깔 등에서 높은 점수를 받았으나 전체적인 품질 에서 된장소스 보다 더 낮은 점수를 받은 것은 배당침액을 소스 제조 과정에서 끓이므로 인해 당이 농축되어 단맛이 강하고 간장냄새가 약간 이취로 나고 색이 진하여 나타난 결과라 생각된다. 그러나 일반 스테이크 소스와 비교했을 때 그 품질이 떨어지지 않아 간장소스의 문제점을 보완하면 앞으로 상업적으로 우수한 간장소스가 될 수 있다고 사료된 다. 된장소스는 배 당침액을 끓이지 않고 원액을 사용하므 로 배당침액의 새콤달콤함이 더 가해져 맛에서 더 높은 평을 받은 것으로 생각된다. 또한 예로부터 마늘과 양파는 우리 식단에 많이 사용되고 있는데 소스의 잡냄새를 제거하 고 식욕을 증진시키는 중요한 역할을 하고 위장의 소화력을 도와주고 장관의 작용을 활성화시키므로 된장소스의 전체 적인 품질 평가가 높은 것으로 사료된다(32).

배당침액을 첨가한 2 종 소스의 기호도를 평가한 결과 (Fig. 3)를 보면 외관과 향미의 기호도는 간장소스와 된장소 스 I이 유사하였다. 간장소스의 기호도는 색깔, 걸죽함, 후미 등( $\mathrm{p}<0.05)$ 이 높게 나타났고, 된장소스 I 은 맛, 오리 훈제와의 조화도, 전반적인 선호도 등 $(\mathrm{p}<0.05)$ 에서 높은 평 가를 받았다. 이러한 결과는 앞서 애기 했듯이 된장소스 I 은 마늘과 양파의 입자가 입안에서 씹히면서 훈제오리 섭취 후 입안에 남았던 기름진 후미를 개운하게 제거를
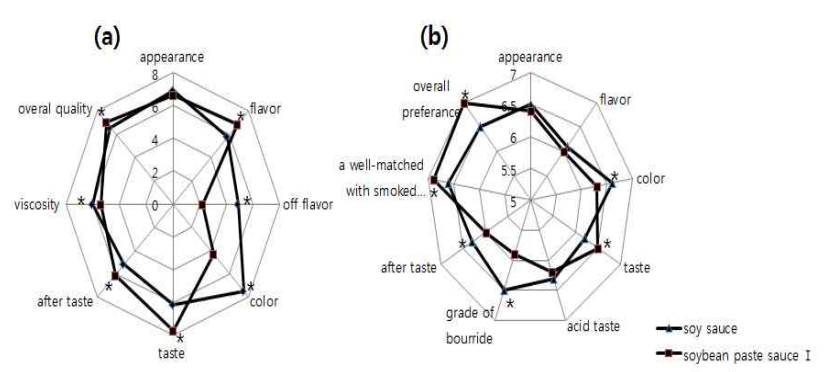

Fig. 3. Sensory evaluation of soy sauce and soybean paste sauce I added with extracts of pear by sugar.

(a), Sensory evaluation; (b), Preference. *Values with different superscripts are significantly different at the $\mathrm{p}<0.05$ by $\mathrm{t}$-test. 
해주고 일반적으로 된장 숙성과정에서 생성된 담백한 맛과 신맛, 단맛 등이 어우러져 일상적으로 한국인의 입맛에 잘 맞기 때문에 훈제오리와도 잘 맞고 전체적인 선호도가 높게 나타났다고 사료된다(31).

\section{일반성분}

신고를 이용한 배당침액의 일반성분 검사 결과는 Table 2 와 같다. 배당침액의 수분함량은 $47.8 \mathrm{~g} / 100 \mathrm{~g}$, 탄수화물 $51.7 \mathrm{~g} / 100 \mathrm{~g}$, 단백질 $0.2 \mathrm{~g} / 100 \mathrm{~g}$, 지방 $0.1 \mathrm{~g} / 100 \mathrm{~g}$, 회분 $0.2 \mathrm{~g} / 100 \mathrm{~g}, \mathrm{Na} 488.6 \mathrm{mg} / 100 \mathrm{~g}, \mathrm{pH} 4.4$ 이었다. 이는 배 과실의 일반성분(2)과 비교할 때 수분함량 $85 ~ 88 \%$ 에서 $50 \%$ 감소한 반면, 탄수화물 중 당 함량이 $10 ~ 13 \%$ 에서 약 $40 \%$ 증가한 것이다. 이러한 결과는 배를 설탕으로 침출하 는 과정에서 삼투압의 원리에 의해 배의 수분이 빠져나오고 저장기간 동안 설탕의 효소에 의한 분해로 당의 함량이 증가한 것으로 사료된다.

배당침액을 이용한 간장소스의 수분 함량은 $71.4 \mathrm{~g} / 100$ $\mathrm{g}$, 탄수화물 $25.1 \mathrm{~g} / 100 \mathrm{~g}$, 단백질 $1.1 \mathrm{~g} / 100 \mathrm{~g}$, 지방 0.1 $\mathrm{g} / 100 \mathrm{~g}$, 회분 $2.3 \mathrm{~g} / 100 \mathrm{~g}$ 이었다. 된장소스의 수분 함량은 $75.1 \mathrm{~g} / 100 \mathrm{~g}$, 탄수화물 $21.1 \mathrm{~g} / 100 \mathrm{~g}$, 단백질 $1.5 \mathrm{~g} / 100 \mathrm{~g}$, 지방 $0.6 \mathrm{~g} / 100 \mathrm{~g}$, 회분 $1.7 \mathrm{~g} / 100 \mathrm{~g}$ 이었다.

Table 2. Proximate composition of extracts of pear by sugar, soy sauce, and soybean paste sauce I added with extracts of pear by sugar

\begin{tabular}{lccc}
\hline & $\begin{array}{c}\text { Extracts of pear } \\
\text { by sugar }\end{array}$ & Soy sauce & $\begin{array}{c}\text { Soybean paste } \\
\text { sauce I }\end{array}$ \\
\hline Energy $(\mathrm{kca} / 100 \mathrm{~g})$ & $208.5 \pm 5.2^{1)}$ & $105.7 \pm 3.6^{*}$ & $95.8 \pm 4.9$ \\
Moisture $(\mathrm{g} / 100 \mathrm{~g})$ & $47.8 \pm 8.3$ & $71.4 \pm 8.5$ & $75.1 \pm 9.5$ \\
Crude fat $(\mathrm{g} / 100 \mathrm{~g})$ & $0.1 \pm 0.0$ & $0.1 \pm 0.0$ & $0.6 \pm 0.0$ \\
Crude protein $(\mathrm{g} / 100 \mathrm{~g})$ & $0.2 \pm 0.0$ & $1.1 \pm 0.0$ & $1.5 \pm 0.0$ \\
Crude ash $(\mathrm{g} / 100 \mathrm{~g})$ & $0.2 \pm 0.0$ & $2.3 \pm 0.0^{*}$ & $1.7 \pm 0.0$ \\
Carbohydrate $(\mathrm{g} / 100 \mathrm{~g})$ & $51.7 \pm 6.7$ & $25.1 \pm 3.5^{*}$ & $21.1 \pm 7.0$ \\
Sugar $(\mathrm{g} / 100 \mathrm{~g})$ & $42.7 \pm 4.1$ & $18.4 \pm 1.0^{*}$ & $11.7 \pm 3.7$ \\
\hline
\end{tabular}

${ }^{1)}$ All values are mean $\pm \mathrm{SD}$.

"Values with different superscripts are significantly different at the $p<0.05$ by $t$-test.

\section{총 폴리페놀 함량}

배당침액과 2종 소스의 총 폴리페놀 함량은 Table 3 과 같다. 배당침액의 총 폴리페놀 함량은 $71.2 \pm 5 \mathrm{mg} / 100 \mathrm{~g}$ 이었 으며 한국산 배 저장기간 동안의 폴리페놀 함량 분석 결과 폴리페놀 함량이 가장 많았던 저장 6 개월째 과피의 73.18 $\mathrm{mg} / 100 \mathrm{~g}$ 과는 유사한 결과였다(33). 그러나 품종별 과실의 총 폴리페놀 함량 분석에 나타난 신고의 $121.3 \mathrm{mg} / 100$ $\mathrm{g}(34)$, 열처리 조건에 따른 한국산 배즙의 특성 연구 결과 폴리페놀 함량이 가장 많았던 $150^{\circ} \mathrm{C} 1$ 시간 처리구의 332. $4 \pm 0.7 \mathrm{mg} / 100 \mathrm{~g}$ 보다는 적었다(35). 이는 배당침액과 배즙 에 함유된 배 추출 성분의 양이 차이가 있어 나타는 결과라
고 사료된다. 그러나 배당침액을 이용한 간장소스의 총 폴 리페놀 함량은 $147.7 \pm 12.6 \mathrm{mg} / 100 \mathrm{~g}$, 된장소스는 $156.2 \pm$ $13.4 \mathrm{mg} / 100 \mathrm{~g}$ 로 두 소스의 총 폴리페놀 함량은 유사하였고 배당침액 보다는 약 2 배의 함량이었다. 이는 소스 제조 원료 로 들어간 발사믹식초, 마늘, 양파, 사과식초 등의 기능성 성분이 더해져 나타난 결과라고 사료된다.

Table 3. Total polyphenol contents and antioxidant activities of extracts of pear by sugar, soy sauce, and soybean paste sauce I added with extracts of pear by sugar

\begin{tabular}{lccc}
\hline \multicolumn{1}{c}{ Item } & $\begin{array}{c}\text { Extracts of pear } \\
\text { by sugar }\end{array}$ & Soy sauce & $\begin{array}{c}\text { Soybean paste } \\
\text { sauce I }\end{array}$ \\
\hline $\begin{array}{l}\text { Total polyphenol } \\
\text { contents (mg/100 g) }\end{array}$ & $71.2 \pm 5.0^{1)}$ & $147.7 \pm 12.6$ & $156.2 \pm 13.4$ \\
DPPH (\%) & $9.7 \pm 3.7$ & $43.6 \pm 6.3^{*}$ & $17.0 \pm 5.0$ \\
ABTS+ (\%) & $14.2 \pm 7.5$ & $18.9 \pm 2.1$ & $17.0 \pm 9.0$ \\
\hline
\end{tabular}

${ }^{1)}$ All values are mean $\pm \mathrm{SD}$.

*Values with different superscripts are significantly different at the $\mathrm{p}<0.05$ by t-test.

\section{항산화활성}

배당침액과 2 종 소스의 항산화활성은 Table 3 과 같다. 배당침액의 항산화 활성을 나타내는 DPPH radical 소거능 은 $9.7 \pm 3.75 \%$ 였고, $\mathrm{ABTS}^{++}$radical 소거능은 $14.2 \pm 7.5 \%$ 였 다. Choi 등(33)은 신고의 DPPH radical 소거능이 $18.9 \%$ 라고 보고하여 본 실험의 배당침액의 결과보다 높았다. 이 러한 결과는 생배즙 원액에 함유되어 있는 폴리페놀 함량이 배당침액에 함유된 폴리페놀 함량보다 많아서 나타난 결과 로 사료된다. 배당침액을 첨가한 2종 소스의 DPPH radical 소거능은 간장소스가 $43.6 \pm 6.3 \%$ 였고 된장소스는 $17.0 \pm 5.0$ $\%$ 로 간장소스가 유의적으로 많았다. $\mathrm{ABTS}^{+}$radical 소거 능은 간장소스 $18.9 \pm 2.1 \%$, 된장소스 $17.0 \pm 9.0 \%$ 로 두 소스 가 유사하였다. 이는 실험 방법에 따라 항산화 활성의 차이 는 보였지만 두 소스에 함유한 총 폴리페놀 성분의 함량이 유사하여 나온 결과라 사료된다. 따라서 소스를 만들 때 물 대신 배당침액을 첨가하면 배즙을 사용하는 것 보다는 재료비를 절감할 수 있고 또한 설탕의 사용량도 줄일 수 있어 재료비 절감 뿐 아니라 마늘, 양파 등 일반 소스 재료의 기능성분에 배의 기능성분이 더해지면서 보다 건강기능성 이 우수한 소스가 만들어진다고 생각된다.

일반적인 간장소스나 된장소스에 배당침액을 소스의 재 료로 사용하여 훈제오리나 스테이크 등의 소스로 개발하여 섭취하면 기존의 배를 첨가하지 않은 소스와는 달리 배를 첨가함으로 인해 배의 기능성을 증가시키는 chlorogenic acid나 quercetin 등의 폴리페놀성 물질의 섭취가 증가할 것으로 사료된다(36). 그리고 된장소스에 부재료로 첨가한 마늘과 양파도 폴리페놀함량이 높고 항암 및 항산화와 항균 활성, 혈액 지질 저하효과, 혈당저하 효과가 높은 식재료이 므로(37-40) 된장소스를 훈제오리 소스로 곁들이면 오리라 
는 건강식품에 기능성이 더 가미된 음식궁합이라 사료된 다. 또한 배당침액을 소스에 첨가함으로 인해 배가 함유하 고 있는 기능성분이 훈제나 육류요리 가열 혹은 흡연이나 공기 중 오염물질에 의해 생성되는 벤조파이렌(benzo [a]pyrene, $\mathrm{B}[\mathrm{a}] \mathrm{P})$ 이나 2-아미노안트라센(2-aminoanthracene, 2-AA)을 비롯한 다환족방향성탄화수소(polycyclic aromatic hydrocarbons, PAHs)를 감소시킬 것으로 사료된다(41).

\section{$\mathrm{pH}$, 당도, 염도 및 미생물 변화}

$4{ }^{\circ} \mathrm{C}$ 에서 60 일 동안 저장한 배당침액 첨가 소스의 $\mathrm{pH}$, 당도 염도, 미생물의 변화에 대한 결과는 Table 4 에 나타내 었다. 소스의 $\mathrm{pH}$, 염도와 미생물 변화는 저장기간에 따라 유의적인 차이를 보이지 않았고, 당도는 간장소스의 경우 유의적인 차이가 없었으나 된장소스는 저장기간이 길어짐 에 따라 유의적으로 증가하여 저장 30 일에는 일정한 당도
를 유지하였다. 이는 된장소스의 된장이 저장기간 동안 발 효할 때 효소의 활성으로 탄수화물이 당분으로 전환되는 당화작용에 의해 단맛이 증가(31)하고 소스의 재료로 들어 간 양파나 마늘의 최루성분이 분해되면서 생성되는 단맛도 영향(42)을 미친것으로 사료된다. 또한 미생물의 변화가 없는 것은 각 소스의 $\mathrm{pH}$ 가 3.63 3.70 사이로 미생물의 최적 $\mathrm{pH}$ 범위에 속하지 않았고 미생물의 잠재적 위험 가능성 범위인 $\mathrm{pH}$ 4.6 7.0 범위에 해당되지 않아 비교적 미생물 생육 범위에서 벗어나 안정적이었기 때문이고 또한 소스의 당도, 염 등이 미생물이 살기에는 적당한 조건이 되지 못하 였기 때문으로 사료된다(43).

\section{색 도}

배당침액을 이용한 2 종 소스의 저장 기간 동안 색도 변화 에 대한 결과는 Table 5 와 같다. 간장소스의 명도, 적색도,

Table 4. Change in physiochemical properties and microbiological characteristics of soy sauce and soybean paste sauce I added with extracts of pear by sugar during storage periods

\begin{tabular}{lcccc}
\hline & & & Storage period (day) & \\
& & 0 & 30 & 60 \\
\hline $\mathrm{pH}$ & Soy sauce & $3.63 \pm 0.1^{1)}$ & $3.67 \pm 0.0$ & $3.70 \pm 0.1$ \\
& Soybean paste sauce I & $3.81 \pm 0.0$ & $3.85 \pm 0.1$ & $3.90 \pm 0.0$ \\
Sweet ( ${ }^{\circ}$ Brix) & Soy sauce & $25.9 \pm 0.2$ & $25.4 \pm 0.1$ & $25.4 \pm 0.1$ \\
& Soybean paste sauce I & $25.9 \pm 0.1^{\mathrm{b}}$ & $26.7 \pm 0.0^{\mathrm{a}}$ & $26.7 \pm 0.2^{\mathrm{a}}$ \\
Salinity (\%) & Soy sauce & $0.9 \pm 0.0$ & $1.1 \pm 0.0$ & $1.1 \pm 0.0$ \\
& Soybean paste sauce I & $0.9 \pm 0.0$ & $0.9 \pm 0.0$ & $0.9 \pm 0.0$ \\
TB2) & Soy sauce & $\mathrm{ND}$ & $\mathrm{ND}$ \\
$\mathrm{CF}$ & Soybean paste sauce I & $\mathrm{ND}$ & $\mathrm{ND}$ & $\mathrm{ND}$ \\
& Soy sauce & $\mathrm{ND}$ & $\mathrm{ND}$ & $\mathrm{ND}$ \\
\hline
\end{tabular}

${ }^{1)}$ All values are mean \pm SD. Different superscripts of $a-b$ in a column means significantly different at $p<0.05$ level by Duncan's multiple range test.
${ }^{2)} \mathrm{TB}$ : total bacteria, $\mathrm{CF}$ : coliform bacteria.

${ }^{3)} \mathrm{ND}$ : Not detected.

Table 5. Change in hunter's color values of soy sauce and soybean paste sauce I added with extracts of pear by sugar during storage periods

\begin{tabular}{lcccc}
\hline & & \multicolumn{3}{c}{ Storage period (day) } \\
& & 0 & 30 & 60 \\
\hline \multirow{2}{*}{ Soy sauce } & L & $6.3 \pm 0.1^{1)}$ & $6.6 \pm 0.0$ & $6.7 \pm 0.1$ \\
& a & $22.2 \pm 0.1$ & $22.3 \pm 0.0$ & $22.0 \pm 0.2$ \\
& b & $10.7 \pm 0.1$ & $11.3 \pm 0.0$ & $11.4 \pm 0.2$ \\
\hline \multirow{3}{*}{ Soybean } & L & $24.8 \pm 0.0$ & $24.7 \pm 0.0$ & $24.3 \pm 0.0$ \\
paste sauce I & a & $14.7 \pm 0.0$ & $13.6 \pm 0.0$ & $13.7 \pm 0.1$ \\
& b & $37.9 \pm 0.2$ & $36.5 \pm 0.0$ & $35.7 \pm 0.1$ \\
\hline
\end{tabular}

${ }^{1)}$ All values are mean $\pm S D$
황색도는 저장기간 동안 유의적인 변화가 없었다. 된장소 스의 명도와 적색도, 황색도 모두 저장기간에 따른 색도 변화는 감소하는 경향을 보였으나 유의적인 차이는 없었 다. 이러한 결과는 두 소스 모두 냉장 저장 하는 동안 색깔의 변화 없이 안정적임을 알 수 있었다.

\section{점 도}

배당침액을 이용한 2 종 소스의 저장 기간 동안 점도 변화 에 대한 결과는 Table 6 과 같다. 간장소스와 된장소스 각각 $\mathrm{rpm}$ 를 달리하여 저장기간 동안의 점도 변화를 분석하였으 며 간장소스는 $120 \mathrm{rpm}$, 된장소스는 $180 \mathrm{rpm}$ 에서의 점도변 화 결과이다. 간장소스는 저장기간이 길어질수록 $744 \pm 3$ $\mathrm{cp}$ 에서 $679 \pm 5 \mathrm{cp}$ 로 유의하게 점도가 감소하였는데 $(\mathrm{p}<0.05)$ 
이러한 결과는 저장기간 동안 간장소스에 들어간 물녹말이 젤의 망상구조가 수축하며 내부에 갇혀 있던 물이 빠져 나오는 이액현상이 발생하기 때문으로(31) 간장소스는 차 후 천연 겔 안정제의 사용을 더 늘리고 전분의 사용을 줄이 므로 인해 오차를 주일 수 있을 것으로 사료된다. 된장소스 의 점도는 $165 \pm 9 \mathrm{cp}$ 에서 $275 \pm 13 \mathrm{cp}$ 로 유의적으로 증가하였 다( $\mathrm{p}<0.05)$. 이는 된장 소스 저장 기간 동안 된장의 발효가 진행되어 수분이 감소하고 걸죽함이 증가해서 나타난 결과 라 생각되며 좀 더 다양한 농도 조절 시험이 차 후 더 필요하 다고 사료된다.

Table 6. Change in viscosity characteristics of soy sauce and soybean paste sauce I added with extracts of pear by sugar during storage periods

\begin{tabular}{cccc}
\hline & \multicolumn{3}{c}{ Storage period (day) } \\
& 0 & 30 & 60 \\
\hline Soy sauce & $744 \pm 3.1^{\mathrm{al})}$ & $688 \pm 2.0^{\mathrm{b}}$ & $679 \pm 5.1^{\mathrm{c}}$ \\
Soybean paste sauce I & $165 \pm 9.0^{\mathrm{c}}$ & $270 \pm 4.0^{\mathrm{b}}$ & $275 \pm 13.0^{\mathrm{a}}$
\end{tabular}

${ }^{11}$ All values are mean \pm SD. Different superscripts of $a-c$ in a column means significantly different at $p<0.05$ level by Duncan's multiple range test.

\section{요 약}

이 연구는 배의 가공식품으로의 활용도를 높이기 위해 배당침액을 제조하고 이를 이용하여 2종 소스(간장소스와 된장소스)를 개발하여 이화학적 특성과 저장성을 알아보고 훈제오리와의 조화도를 평가하여 육류요리와 어울리는 소 스로서의 가능성을 제안하고자 하였다. 2 종 소스는 이론적 인 레시피와 다량조리 실험과 관능평가를 통하여 최종 레시 피를 결정하였다. 또한 된장소스는 관능평가에 재료의 입 자 크기가 미치는 영향을 최소한으로 줄이고자 마늘과 양파 를 $0.2 \mathrm{~cm}$ 크기로 다진 것과 분쇄기에 분쇄한 두 가지 형태 (된장소스 I, II)로 제조하여 관능평가 실시하여 그 결과 최종 소스를 확정하여 이후 이화학적 분석의 시료로 사용하 였다. 된장소스 I이 강도 관능평가에서 향미, 색깔, 맛, 전체적인 품질이 더 높게 평가되었고 $(\mathrm{p}<0.05)$ 기호도 평가 에서는 색깔, 맛, 산미, 훈제오리와의 조화도, 전체적인 선 호도 에서 된장소스 피보다 더 높은 점수를 받았다 $(\mathrm{p}<0.05)$. 따라서 된장소스 I 을 선택하여 차 후 이화학적 분석 시료 로 사용하였다. 간장소스와의 관능평가 결과 이취, 색깔, 점도는 간장소스가 유의적으로 된장소스 I 보다 더 높았으 며 $(\mathrm{p}<0.05)$ 냄새, 맛, 후미, 전체적인 품질은 된장소스 I 이 유의적으로 더 높았다 $(\mathrm{p}<0.05)$. 두 소스의 기호도 평가에서 는 된장소스 I이 맛, 오리훈제와의 조화도, 전반적인 기호 도 등에서 유의적으로 점수가 높았다 $(\mathrm{p}<0.05)$. 배당침액의 총 폴리페놀 함량은 $71.2 \pm 5 \mathrm{mg} / 100 \mathrm{~g}$ 이었고 DPPH radical
소거능은 $9.7 \pm 3.7 \%, \mathrm{ABTS}^{+{ }^{+}}$radical 소거능은 $14.2 \pm 7.5 \%$ 였다. 배당침액을 첨가한 소스의 총 폴리페놀 함량은 간장 소스 $147.7 \pm 12.6 \mathrm{mg} / 100 \mathrm{~g}$, 된장소스 $156.2 \pm 13.4 \mathrm{mg} / 100$ $\mathrm{g}$ 로 두 군이 유사하였다. 항산화 활성을 나타내는 $\mathrm{DPPH}$ radical 소거능은 간장소스 $43.6 \pm 6.3 \%$, 된장소스 $17.0 \pm 5.0 \%$ 로 간장소스의 활성이 높았고, $\mathrm{ABTS}{ }^{+{ }^{+}}$radical 소거능은 간장소스 $18.9 \pm 2.1 \%$, 된장소스 $17.0 \pm 9.0 \%$ 로 두 소스가 유 사하였다. 개발된 두 소스의 저장성 평가에서 $\mathrm{pH}$, 염도, 미생물, 색도의 변화는 저장기간 동안 유의하지 않았고 당 도는 간장소스 경우 저장기간에 따라 차이가 없었으나 된장 소스는 증가하였다. 점도변화는 간장소스는 저장기간이 길 어질수록 점도가 감소하였고, 된장소스는 증가하였다. 결 론적으로 저장기간 동안 소스의 점도변화를 안정화시키면 배당침액을 첨가한 간장소스와 된장소스는 약간의 차이를 보이지만 배와 배당침액, 마늘, 양파 등 각 소스 재료의 다양한 기능성분을 함유하면서 항산화활성이 높고 저장성 이 안정적인 육류 요리 소스로서 활용 가능성이 높다고 사료된다.

\section{감사의 글}

본 논문은 2015년도 송원대학교 학술연구비(과제번 호:C201501) 지원에 의하여 수행되었으며, 이에 감사드립 니다.

\section{References}

1. Ahn YB, Kang KM, Kim JH, Park LY, Lee SH (2014) Quality characteristics of fermented wild grass juice. J Korean Soc Food Sci Nutr, 43, 1731-1736

2. Kim JB (2003) Story of our pear, National Institute of Horticultural \& Herbal Science. Horticulture research, Suwon, Korea, p 18-22

3. Zhang UB, Choi HJ, Han HS, Park JH, Son JH, Bae JH, Seong TS, An BJ, Kim HG, Choi C (2003) Chemical structure of polyphenol isolated from Korean pear (Pyrus pyrifolia Nakai). Korean J Food Sci Tech, 35, 959-967

4. Rosa M. Raybaudi M, Jonathan MM, Olga MB (2009) Antimicrobial activity of malic acid against Listeria monocytogenes, Salmonella Enteritidis and Escherichia coli $0157: H 7$ in apple, pear and melon juices. Food Control, 20, 105-112

5. Kim DC, Chae HJ, In MJ (2010) Fermentation characteristics of Korean pear (Pyrus pyrifolia Nakai) puree by the Leuconostoc mesenteroides 51-3 strain 
isolated from kimchi. Afr J biotech, 9, 5735-5738

6. Lee DH, Kim JH, Lee JS (2009) Effect of pears on the quality an physiological functionality of makgeoly. Korean J Food Nutr, 22, 606-611

7. Song JH, Chun JP, Na KC, Moon JH, Kim WS, Lee JS (2009) Optimal fermentation condition for development of high quality pear wine and characteristics of pear wines. Korean J Microbiol Biotech, 37, 213-218

8. Korea Food Research Institute (2002) Development of lactic acid bacteria fermented drink products using pear and vegetables, Ministry of Agriculture and Forestry, GA, 0315-0207

9. Gorny JR, Hess-Pierce B, Cifuentes RA, Kader AA (2002) Quality changes in fresh-cut slices as affected by controlled atmospheres and chemical preservatives. Postharvest Biol Technol, 24, 271-278

10. Park YO, Choi JH, Choi JJ, Yim SH, Lee HC, Yoo MJ (2011) Physicochemical characteristics of yanggaeng with pear juice and dried pear powder added. Korean J Food Preserv, 18, 692-299

11. Choi SK, Choi HS (2006) Cuisine and Sauce. Hyungseul Publishing, Seoul, Korea, p 10-11

12. Yin XF, Choi SK, Namkung Y (2011) Quality characteristics of soy reducing sauce made with apple concentrate. J East Asian Soc Dietary Life, 21, 823-928

13. Nam JS, Choi SK, Kim DS (2010) Quality and sensory characteristics of Bulgogi sauce with various amount of Omija extract juice. Korean J Culinary Res, 16, 247-259

14. Oh HS, Kim JH (2006) Development of functional soy based stew sauce including hot water extract of Comus officinalis S. et Z. Korean J Food Culture, 20, 550-558

15. Oh HS, Park B (2003) Studies on the making of Teriyaki sauce using Korean soy sauce. Korean J Culinary Res, 9, 102-113

16. Oh KH, Song HS (2013) Sensory evaluation of seasoned soy sauce with Hutagae (Hovenia dilcis Thunb) fruit and pear extracts. Korean J Food Nutr, 26, 323-328

17. Joo HK, Oh KT, Kim DH (1992) Effects of mixture of improved Meju, Korean traditional Meju and Natto on soybean paste fermentation. J Korean Agric Chem Soc, 35, 286-293

18. Pratt DE, Pietro CD, Paster WL, Giffee JW (1981) Phenolic antioxidants of soy protein hydrolyzates. J Food Sci, 47, 24-25

19. Esaki H, Nohara Y, Onizaki H, Osawa T (1990) Antioxidative activity of natto. Nippon Shosuhin Kogyo Gakkaishi, 37, 474-477
20. Shin ZI, Yu R, Park SA, Chung DK, Ahn CW, Nam HS, Kim KS, Lee HJ (2001) His-his-leu, an angiotensin I converting enzyme inhibitory peptide derived from Korean soybean paste, extracts antihypertensive activity in vivo. J Agric Food Chem, 49, 3004-3009

21. Kim YT, Kim WK, Oh HI (1995) Screening and identification of the fibrinolytic bacterial strain from Chungkookjang. Korean J Appl Microbiol Biotechnol, 23, $1-5$

22. Chang KH, Cho KH, Kang MK (2012) Optimization of the preparation conditions and quality characteristics of sweet pumpkin-doenjang sauce. Korean J Food Preserv, 19, 492- 500

23. Joo NM, Jung HS, Yoon JY, Park SH, Lee SM, Song YH, Lee JH (2010) Development and application of soybean paste sauce with walnuts and sesame seeds. Korean J Culinary Res, 16, 298-306

24. Choi SK, Sung TG (2014) Sauce school. Haseo Publishing Co., Seoul, Korea, p 37-137

25. Choi SJ, Park KY (2014) Fermented soybean paste is good in our's body. Leescom Publishing Co., Seoul, Korea, p 174

26. Yoon HS, Joo SJ, Kim KS, Kim SJ, Kim SS, Oh MH (2006) Quality characteristics of pork cutlet sauce added with rice soybean paste powder. Korean J Food Preserv, 13, 472-476

27. Korea Food Industry Association (2001) Food Code, p 539-564

28. Swain T, Hillis WE (1959) The phenolic constituents of prunusdomestica 1-the quantitative analysis of phenolic constituents. J Sci Food Agric, 10, 63-68

29. Lee YU, Huang GW, Liang ZC, Mau JL (2007) Antioxidant properties of three extracts from Pleurotus citrinopileatus. LWT Food Sci Technol, 40, 823-833

30. Shiddhuraju P, Mohan PS, Becker K (2002) Studies on the oxidant activity of Indian laburnum (Cassia fistula L) : a preliminary assessment of crude extracts from stem bark, leaves, flowers and fruit pulp. Food Chem, 79, 61-67

31. Lee JH, Kim ML, Min HS, Lee YY, Song YS, Kwon SJ, Kim MJ, Song HN (2012) The food \& principle of cookery, Kyomunsa Publishing Co., Paju, Korea, p 71, 130-140

32. Lee JH, Kim MR (2008) Changes in the functional properties of spices and herbs during cooking. Korean J Food Cookery Sci, 24, 132-156

33. Zang YB, Bae MJ, An BJ, Choi HJ, Bae JH, Kim S, Choi C (2003) Effect of antioxidant activity and change 
in quality of chemical composition and polyphenol compound during long-term storage. Korean J Food Sci Technol, 35, 115-120

34. Choi JJ, Lim SH, Choi JH, Park JH, Nam SH, Lee HC (2013) Antioxidant activity of Pyrus pyrifolia fruit in different cultivars and parts. Korean J Food Preserv, 20, 222-226

35. Hwang IG, Woo KS, Kim TM, Kim DJ, Yang MH, Jeong HS (2006) Change of physicochemical characteristics of Korean pear (Pyrus pyrifolia Nakai) juice with heat treatment conditions. Korean J Food Sci Technol, 38, 342-347

36. Zhang UB, Choi HJ, Han HS, Park JH, Son JH, Bae JH, Seong TS, An BJ, Kim HG, Choi C (2003) Chemical structure of polyphenol isolated from Korean pear (Pyrus pyrifolia Nakai). Korean J Food Sci Technol, 35, 959-967

37. Jung KA, Park CS (2013) Antioxidative and antimicrobial activities of juice from garlic, ginger, and onion. Korean J Food Preserv, 20, 134-139
38. Nakagawa H, Tsubura A(2001) Growth inhibitory effects of dially disulfide on human breast cancer cell lines. Carcinogenesis, 22, 891-897

39. Miean KH, Mohamed S (2001) Flavonoid (myricetin, quercetin, kaempferol, luteolin, and apigenin) content of edible tropical plants. J Agric Food Chem, 49, 3106-3112

40. Chung HK, Shin MJ, Cha YJ, Lee KH (2011) Effect of onion peel extracts on blood lipid profile and blood coagulation in high fat fed SD rats. Korean J Food Nutr, $24,442-450$

41. Yang MH (2006) Functional studies of the heart, and the Korean pear orchard. Korean J Sci Tech, 24, 50-56

42. Lee SY, Jeong HJ, Lee YY, Kim ML, Kim ML(b), Song HN (2013) Food chemistry. Powerbook Publishing Co., Seoul, Korea, p 355-357

43. Kim HD, Yim SB, Oh HL, Jeon HY, Kim CR, Kim NY, Hong YP, Lee JH, Kim MR (2012) The quality characteristics and antioxidant activity of extracts of sahisandra chinensis Baillon salad dressing prepared with yam juice and mulberry. Korean J Food Cookery Sci, $28,531-540$ 